\title{
The Effect of Dissolved Oxygen Concentration on the Growth Physiology of Saccharomyces cerevisiae whi2 Mutants
}

\author{
By D. R. J. RAHMAN, ${ }^{1}$ P. E. SUDBERY, ${ }^{1}{ }^{*}$ S. KELLY ${ }^{1}$ AND \\ I. W. MARISON ${ }^{2}$ \\ ${ }^{1}$ Department of Genetics and Wolfson Institute of Biotechnology, University of Sheffeld, \\ Sheffield S10 2TN, UK \\ ${ }^{2}$ Institute of Chemical Engineering, Swiss Federal Institute of Technology, CH-1015 Lausanne, \\ Switzerland
}

(Received 12 October 1987; revised 28 April 1988)

\begin{abstract}
Isogenic whi2 and $\mathrm{WHI}^{+}$strains of Saccharomyces cerevisiae were grown in a 2-litre bioreactor as batch cultures on a medium containing yeast extract and peptone with either glucose or ethanol as carbon and energy source. The concentration of dissolved oxygen within the medium was varied over the range of 0 to $100 \%$ saturation. Expression of the whi 2 phenotype only occurred above $40 \%$ oxygen saturation with either glucose or ethanol as carbon and energy source. Under these conditions the whi2 cells could be distinguished from $\mathrm{WHI}^{+}$cells in that they were phase dark, highly budded and very small during the stationary growth phase, and reached final cell densities four to six times higher than $W H I 2^{+}$cells. The results clearly show that the $W H I 2$ gene of $S$. cerevisiae plays an important role in cell proliferation and that the availability of oxygen, or some product of oxidative metabolism, is involved in regulating the phenotypic expression of mutations within this gene.
\end{abstract}

\section{INTRODUCTION}

whi 2 mutants of Saccharomyces cerevisiae lack the normal coordination of cell proliferation with nutrient availability (Sudbery et al., 1980). Thus aerobic, batch cultivation of the parent $\left(\mathrm{WHI}^{+}\right)$cells on YPG (yeast extract, $1 \%$; peptone, $2 \%$; glucose, $2 \%$, w/v) medium results in cessation of cell proliferation at the onset of the stationary phase as a result of the exhaustion of the main carbon and energy source. Under these conditions the cell cycle arrests in the G1 phase with the majority of the cells in the unbudded state (Hartwell, 1974). By contrast, whi2 cells continue to divide well into stationary phase and do not recognize the depletion of the carbon source. As a result of this division without cell growth the cells become smaller and attain a higher final cell concentration. When cell proliferation eventually ceases, presumably due to the exhaustion of the energy source or some other component of the medium, the cells arrest randomly within the cell cycle (Sudbery et al., 1980).

A concerted series of physiological changes occurs with parent $\mathrm{WHI}^{+}$cells upon initiation of the stationary phase which results in distinct differences compared to exponentially growing cells. Stationary-phase cells are more resistant to a $52^{\circ} \mathrm{C}$ heat shock (Parry et al., 1976; Schenberg-Frascino \& Moustacchi, 1972), to nystatin treatment (Snow, 1966) and to spheroplast formation (Deutch \& Parry, 1973). In addition they appear phase bright (exponentially growing cells appear phase dark), and contain a higher proportion of glycogen and trehalose (Lillie \& Pringle, 1980).

Abbreviation: $\mathrm{dO}_{2}$, dissolved oxygen. 
Under glucose-limited conditions, stationary-phase whi 2 cells retain the properties of exponentially growing cells and do not exhibit the physiological changes associated with wildtype cells (Sudbery et al., 1980; Saul et al., 1985). During growth on relatively poor carbon and energy sources such as glycerol, acetate and ethanol, whi2 cells exhibit a specific growth rate much higher than that of $W_{H} 2^{+}$cells (Walton, 1984).

These differences between the parent $\mathrm{WHI}^{+}$and mutant cells indicate that the $W H I 2$ gene plays an important role in the perception of the nutrient status of the environment or the ability of the cell to respond to changes in the environment in terms of cell size, growth rate and cell proliferation. The mechanism by which the $W H I 2$ gene effects or controls the physiological response of the cells is not known. Since the environment plays an important role in the expression of the whi2 phenotype, we have examined the physiological differences between the mutant and parent under conditions where the dissolved oxygen concentration has been carefully controlled.

\section{METHODS}

Culture strains. The wild-type parent strain $\left(W H I^{+}\right)$of $S$. cerevisiae X4003-5B (a ade1 his 4 met 2 ura 3 trp 5 ) was obtained from the Yeast Stock Center, Berkeley, California, USA. The isogenic whi2 mutant (ISO34) ( $\alpha$ whi2 his 4 trp5 leu2) has been previously described (Saul et al., 1985).

Media and culture conditions. Cultures were grown on a YPG medium, containing Difco yeast extract $\left(10 \mathrm{~g} \mathrm{l}^{-1}\right)$, Difco Bacto-peptone $\left(20 \mathrm{~g}^{-1}\right)$ and glucose $\left(20 \mathrm{~g} \mathrm{l}^{-1}\right)$, at $\mathrm{pH} 6.5$ and $30^{\circ} \mathrm{C}$, unless otherwise stated. When ethanol was used as the carbon and energy source the glucose was replaced by ethanol $\left(10 \mathrm{~g} \mathrm{l}^{-1}\right)$. Media were sterilized at $121{ }^{\circ} \mathrm{C}$ for $20 \mathrm{~min}$ with the exception of ethanol, which was filter-sterilized separately and added to the cooled, sterile medium.

All cultures were maintained on Petri dishes containing YPG medium plus Bacto-agar (Difco, $15 \mathrm{~g} \mathrm{l}^{-1}$ ) and were transferred monthly. Inocula for the 2-litre bioreactor were prepared by adding $100 \mathrm{ml}$ of YPG, or YPethanol, medium to a 1-litre, cotton-wool-stoppered side-armed flask followed by inoculation with $3 \mathrm{ml}$ of a culture previously grown on the same medium and originally obtained from a single colony. The flasks were incubated at $30^{\circ} \mathrm{C}$ on a rotary shaker for $12-16 \mathrm{~h}$, before using the whole contents as inoculum for the bioreactor.

A 2-litre (1.5 litre working volume) bioreactor (LSL Ltd) with temperature, $\mathrm{pH}$ and dissolved oxygen $\left(\mathrm{dO}_{2}\right)$ measurement and control was used for all batch culture experiments. $\mathrm{dO}_{2}$ control was accomplished through PIDcontrol (proportional-integral-differential control) of the agitator speed. Cultures in which the $\mathrm{dO}_{2}$ was maintained above $40 \%$ saturation were supplied with 1 v.v.m. air (volume air per volume medium per minute). Below $40 \%$ saturation, nitrogen was supplied to the medium to lower the oxygen tension to the desired set-point value before inoculation. Air was then supplied at a rate of 0.2 v.v.m. except when the desired set-point was less than $10 \%$ saturation. The operating temperature was maintained constant at $30^{\circ} \mathrm{C}$.

After inoculation samples $(22 \mathrm{ml})$ were removed from the bioreactor at intervals for the determination of cell and substrate concentration.

Determination of cell concentration. Cell concentration was determined in terms of optical density, cell dry weight $\left(\mathrm{g}^{-1}\right)$ and total cell number (cells $\mathrm{ml}^{-1}$ ).

Optical density measurements were determined at $600 \mathrm{~nm}$ using a Pye-Unicam SP 800 double-beam spectrophotometer against a water reference. Care was taken to dilute samples such that $\mathrm{OD}_{600}$ measurements were directly proportional to cell number.

Cell dry weight was determined by centrifugation of culture samples $(10 \mathrm{ml})$ at $15000 \mathrm{~g}$ for $10 \mathrm{~min}$, washing the cell pellet with $\mathrm{NaCl}\left(9 \mathrm{~g}^{-1}\right)$, re-centrifuging and placing the pre-weighed tubes containing cell pellet at $90^{\circ} \mathrm{C}$ until the weight remained constant $(15-18 \mathrm{~h})$. Total cell number was determined microscopically using a graduated counting slide (haemocytometer).

Determination of cell size. This was done using a Coulter counter model ZB1, C1000 analyser and slave recorder which had been calibrated using latex beads (diameter $4.63 \mu \mathrm{m}$ ) as size standards.

Determination of glucose. The residual glucose content of the culture samples was determined by centrifugation $(15000 \mathrm{~g}$ for $10 \mathrm{~min}$ ) of the samples to remove cell material. The supernatant was then assayed enzymically using a glucose oxidase/peroxidase system coupled to the formation of 4-(p-benzoquinone-mono-imino)phenazone which was measured spectrophotometrically at $510 \mathrm{~nm}$ (Boehringer Mannheim automated analysis system 166391) and compared to a standard curve prepared with glucose $\left(0-100 \mu \mathrm{g} \mathrm{ml}^{-1}\right)$.

Ethanol determination. Cell-free culture samples were injected into a gas chromatograph (Shimadzu model GCMini-1) fitted with a $2 \mathrm{~m}$ glass column containing Porapak $\mathrm{Q}$ as packing material. The column temperature was $125^{\circ} \mathrm{C}$ with a carrier gas $\left(\mathrm{N}_{2}\right)$ flow rate of $30 \mathrm{ml} \mathrm{min}^{-1}$. Acetone was used as internal standard. 


\section{RESULTS AND DISCUSSION}

\section{Batch culture growth on $Y P G$}

$\mathrm{WHI}^{+}$and whi2 strains of $S$. cerevisiae were grown as batch cultures in the 2-litre bioreactor containing 1.51 YPG medium plus $0.2 \mathrm{ml}$ antifoaming agent (Sigma, Antifoam A) $1^{-1}$. The $\mathrm{dO}_{2}$ concentration was maintained constant throughout each experiment by automatically controlling the agitation speed. The $\mathrm{dO}_{2}$ concentration was measured using a sterilizable polarographic electrode which resulted in the $\mathrm{dO}_{2}$ concentration varying from the set-point by no more than $\pm 6 \%$.

Typical batch growth curves for the mutant (whi2) grown at 0,40 and $>70 \%$ oxygen saturation of the medium are shown in Figs $I(a),(b)$ and $(c)$, respectively. Similar growth curves, with the exception of the total cell number, were obtained with the $W H L^{+}$strain under similar conditions.

At low $\mathrm{dO}_{2}$ concentrations ( $<40 \%$ saturation) both $\mathrm{WHI}^{+}$and whi2 strains followed a basically anaerobic growth pattern in which cell dry weight and ethanol concentration increased, reaching a maximum $8-10 \mathrm{~h}$ after inoculation. The ethanol formed during this initial growth phase was not subsequently oxidized by the cells. The results (Table 1) showed no significant difference between the two strains in terms of specific growth rate $(\mu)(0 \cdot 23-$ $\left.0.24 \mathrm{~h}^{-1}\right)$, final cell density $\left(0.96 \times 10^{8}\right.$ cells $\left.\mathrm{ml}^{-1}\right)$, final cell volume $\left(34-36 \mu \mathrm{m}^{3}\right)$, or the proportion of budded cells observed during the stationary phase $(6 \cdot 1-6 \cdot 5 \%)$.

When the $\mathrm{dO}_{2}$ was increased above $40 \%$ saturation, significant differences were observed between the two strains with respect to total cell number, cell volume and the percentage of budding cells observed in the stationary phase (Table 1). Thus at the onset of stationary phase the total cell number of the whi2 strain $\left(5.71-5.77 \times 10^{8} \mathrm{ml}^{-1}\right)$ was more than threefold higher than that of the $W H I^{+}$strain $\left(1.77-1.78 \times 10^{8} \mathrm{ml}^{-1}\right)$. However, the biomass yield coefficient, $Y_{\mathrm{x} / \mathrm{s}}$, for whi2 was approximately $27 \%$ lower than for $W H 2^{+}$(Table 1 ), indicating that less of the substrate carbon had been conserved as biomass. Recent calorimetric experiments (unpublished

Table 1. Effect of $\mathrm{HO}_{2}$ concentration on the growth and cell size distribution of strains X4003-5B $\left(\mathrm{WHI}^{+}\right)$and ISO34 (whi2)

\begin{tabular}{|c|c|c|c|c|c|c|}
\hline $\begin{array}{l}\text { Strain } \\
\text { genotype }\end{array}$ & $\begin{array}{c}\text { Oxygen } \\
\text { saturation } \\
(\%)\end{array}$ & $\begin{array}{c}\mu \\
\left(\mathrm{h}^{-1}\right)^{*}\end{array}$ & $Y_{x / s}{ }^{\dagger}$ & $\begin{array}{c}10^{-8} \times \text { Final cell } \\
\text { density } \\
\left(\text { cells } \mathrm{ml}^{-1}\right) \ddagger\end{array}$ & $\begin{array}{c}\text { Final cell } \\
\text { volume } \\
\left(\mu \mathrm{m}^{3}\right)\end{array}$ & $\begin{array}{l}\text { Budded } \\
\text { cells } \\
(\%) \S\end{array}$ \\
\hline WHI2 & $\begin{array}{r}0 \\
10 \\
20 \\
40\end{array}$ & $\begin{array}{l}0.23( \pm 5 \%) \\
0.26( \pm 4.8 \%) \\
0.21( \pm 6.2 \%) \\
0.24( \pm 3.2 \%)\end{array}$ & $\begin{array}{l}0.16( \pm 1.8 \%) \\
0.19( \pm 0.8 \%) \\
0.16( \pm 1.2 \%) \\
0.16( \pm 2.1 \%)\end{array}$ & $\begin{array}{l}0.96 \\
1.21 \\
1.50 \\
1 \cdot 77\end{array}$ & $\begin{array}{l}34 \\
36 \\
35 \\
35\end{array}$ & $\begin{array}{l}6 \cdot 2 \\
6 \cdot 1 \\
3 \cdot 8 \\
4 \cdot 7\end{array}$ \\
\hline & $\begin{array}{r}50 \\
>70\end{array}$ & $\begin{array}{c}\text { ND } \\
0.23( \pm 4.6 \%) \\
{[0.06( \pm 5.2 \%)]}\end{array}$ & $0.26( \pm 1.6 \%)$ & $\begin{array}{l}\text { ND } \\
1.78\end{array}$ & $\begin{array}{l}\text { ND } \\
30\end{array}$ & $\begin{array}{l}\text { ND } \\
6.5\end{array}$ \\
\hline whi2 & $\begin{array}{r}0 \\
10 \\
20 \\
40 \\
50\end{array}$ & $\begin{array}{l}0.24( \pm 3.1 \%) \\
0.23( \pm 4.2 \%) \\
0.23( \pm 2.9 \%) \\
0.25( \pm 3.8 \%) \\
0.30( \pm 3.2 \%)\end{array}$ & $\begin{array}{l}0.18( \pm 1.2 \%) \\
0.17( \pm 1.9 \%) \\
0.17( \pm 1.3 \%) \\
0.15( \pm 1.1 \%) \\
0.20( \pm 1.3 \%)\end{array}$ & $\begin{array}{l}0.96 \\
1.32 \\
1.72 \\
1.58 \\
5 \cdot 77\end{array}$ & $\begin{array}{c}36 \\
35 \\
36 \\
16-39 \\
18\end{array}$ & $\begin{array}{c}6 \cdot 8 \\
6 \cdot 2 \\
5 \cdot 9 \\
6 \cdot 3 \\
26\end{array}$ \\
\hline & $>70$ & $\begin{array}{c}0.32( \pm 3.8 \%) \\
{[0.11( \pm 5.3 \%)]}\end{array}$ & $0.18( \pm 1.6 \%)$ & 5.71 & 16 & 32 \\
\hline
\end{tabular}

ND, Not determined.

- The results are shown \pm the maximum percentage variation observed. Numbers in square brackets represent values for the subsequent growth phase on ethanol.

+ Units: $g$ cell dry weight formed ( $\mathrm{g}$ glucose consumed) ${ }^{-1}$. The results are shown \pm the maximum percentage variation observed.

$\ddagger$ Mean value determined from a minimum of five samples.

$\S$ Figures represent the percentage of budded cells found during the stationary phase of growth from a total of $10^{3}$ cells counted. 

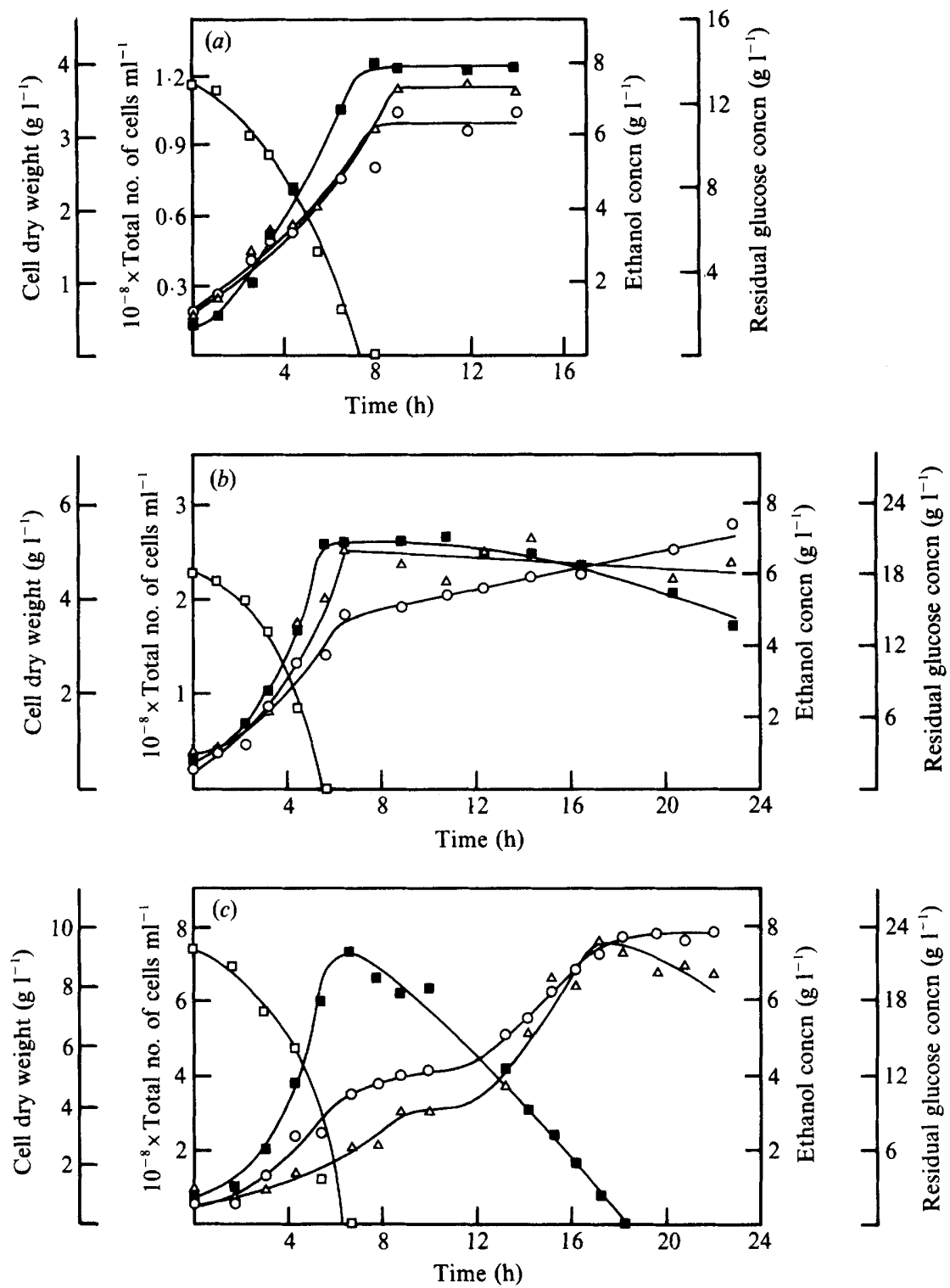

Fig. 1, Batch culture growth of $S$. cerevisiae ISO34 (whi2) on YPG medium at different $\mathrm{dO}_{2}$ concentrations: $(a) 0 \%,(b) 40 \%$ and $(c)>70 \%$ saturation of the medium with oxygen. $O$, Cell dry weight; $\triangle$, total number of cells $\mathrm{ml}^{-1} ; \square$, residual glucose concentration; $\square$, ethanol concentration.

data) suggest that the lower yield is due to a less efficient coupling of substrate oxidation to biosynthesis, with a considerable amount of the energy available within the substrate being lost as heat.

The result of a high cell number and low biomass yield is reflected in the small size of the whi 2 cells $\left(16-18 \mu \mathrm{m}^{3}\right)$ compared with $W H 2^{+}\left(30-36 \mu \mathrm{m}^{3}\right)$ (Fig. 2, Table 1).

A further major difference between the $\mathrm{WHI}^{+}$and whi2 strains was the high degree of budding of the latter after exhaustion of the carbon source. Thus the $W H I 2^{+}$cells occurred as individual or small clumps of unbudded cells, budded cells representing $3 \cdot 8-6 \cdot 5 \%$ of the total cell population, suggesting that upon exhaustion of the carbon source the cells arrest in the G1 stage of the cell cycle (Hartwell, 1974). The whi2 cells appear to arrest randomly within the growth 


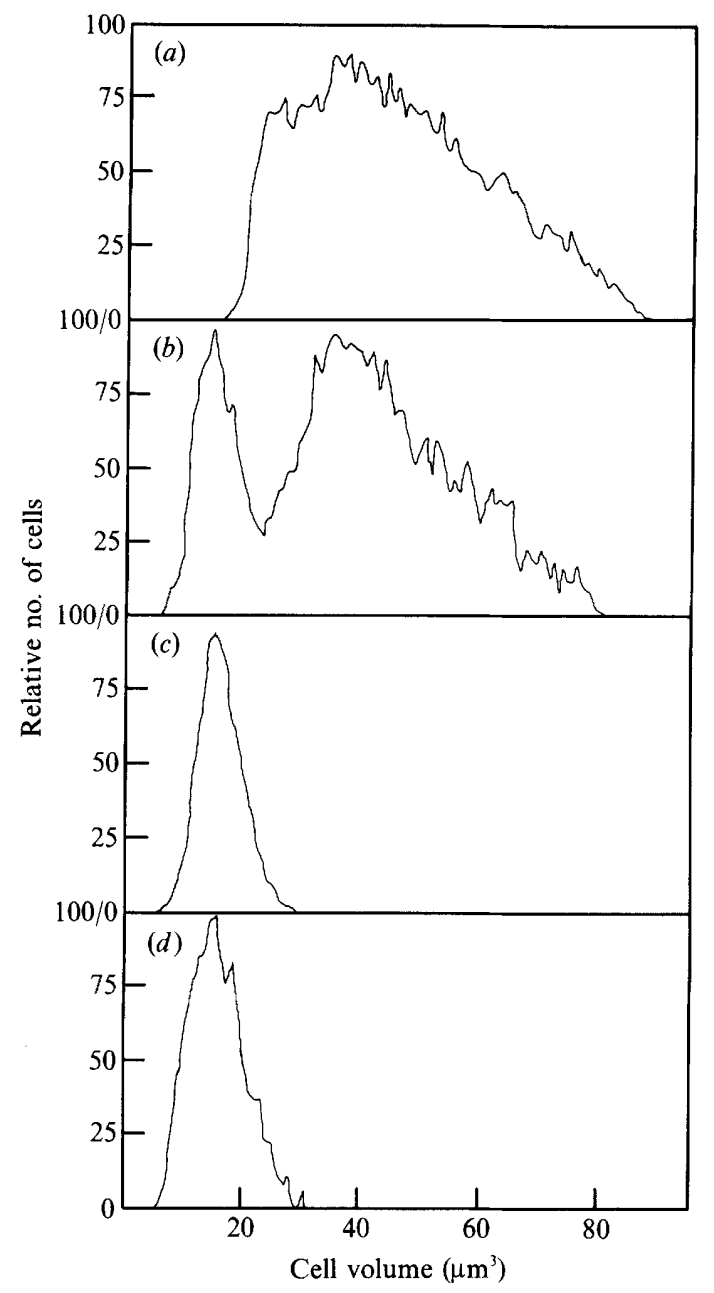

Fig. 2. Ceil size (volume, $\mu \mathrm{m}^{3}$ ) distribution for $S$. cerevisiae ISO34 (whi2) during the stationary phase of batch growth on YPG medium at different $\mathrm{dO}_{2}$ concentrations: $(a) 0 \%,(b) 40 \%,(c) 50 \%$ and $(d)>70 \%$ saturation of the medium with oxygen.

cycle (Sudbery et al., 1980) and were consequently highly budded (26-32\% of the total cell population).

At a $\mathrm{dO}_{2}$ concentration of $40 \pm 6 \%$ saturation, a situation midway between that for highly aerobic and anaerobic conditions was obtained (Table 1, and Fig. 2). The growth rate and final cell density for the $\mathrm{WHI}^{+}$and whi2 strains were similar; however, two distinct peaks were observed for cell size distribution, the first $\left(16 \mu \mathrm{m}^{3}\right)$ characteristic of the whi2 phenotype and the second $\left(39 \mu \mathrm{m}^{3}\right)$ characteristic of the $W H I 2^{+}$phenotype (Fig. 2). It is interesting that no cells of intermediate phenotype were observed, suggesting that cells expressing the phenotype are in a discrete state, entry into which is controlled by a critical $\mathrm{dO}_{2}$ level.

\section{Batch culture growth on YP-ethanol}

During batch growth on YPG medium, yeast cultures show diauxic growth. During the first phase cells consume glucose, which is metabolized fermentatively even in the presence of oxygen (Lagunas, 1986), and excrete ethanol. During the second phase the cells consume this ethanol, metabolizing it aerobically. $\mathrm{WHI}^{+}$and whiz cells are identical during the first phase 
Table 2. Physiological characteristics of strains $X 4003-5 B\left(W_{H}{ }^{+}\right)$and ISO34 (whi2) grown aerobically on YP-ethanol medium

$\begin{array}{lccccc}\begin{array}{c}\text { Strain } \\ \text { genotype }\end{array} & \begin{array}{c}\text { Oxygen } \\ \text { saturation } \\ (\%)\end{array} & \begin{array}{c}\mu \\ \left(\mathrm{h}^{-1}\right)\end{array} & \begin{array}{c}10^{-8} \times \text { Final cell } \\ \text { density } \\ \left.(\text { cells ml })^{-1}\right)^{*}\end{array} & \begin{array}{c}\text { Final cell } \\ \text { volume } \\ \left(\mu \mathrm{m}^{3}\right)\end{array} & \begin{array}{c}\text { Budded } \\ \text { cells } \\ (\%) \dagger\end{array} \\ W_{\text {WH }} \mathbf{2}^{+} & >70 & 0.09 & 1.44 & 36 & 7 \cdot 1 \\ \text { whi } 2 & >70 & 0.16 & 7.82 & 12 & 35\end{array}$

* Mean value determined from a minimum of five samples.

$\dagger$ These figures represent the percentage of budded cells found during the stationary phase of growth from a total of $10^{3}$ cells counted.

Table 3. Physiological characteristics of $\mathrm{WHI}^{+}$and whi2 strains after transfer from $\mathrm{YPG}$ medium at $0 \% \mathrm{O}_{2}$ saturation to $>70 \% \mathrm{O}_{2}$ saturation

\begin{tabular}{|c|c|c|c|c|}
\hline & \multicolumn{2}{|c|}{$0 \% \mathrm{O}_{2}$ saturation } & \multicolumn{2}{|c|}{$>70 \% \mathrm{O}_{2}$ saturation } \\
\hline & WHI $2^{+}$ & whi2 & $\mathrm{WHI}^{+}$ & whi2 \\
\hline$\mu\left(\mathrm{h}^{-1}\right)^{*}$ & $0 \cdot 20( \pm 3 \cdot 1 \%)$ & $0.26( \pm 2.4 \%)$ & ND & ND \\
\hline$\left.Y_{\mathrm{x} / \mathrm{s}}{ }^{*}[\mathrm{~g} \text { cell dry wt (g glucose })^{-1}\right]$ & $0.12( \pm 1.6 \%)$ & $0.15( \pm 1.4 \%)$ & ND & ND \\
\hline $10^{-8} \times$ Final cell density (cells $\mathrm{ml}^{-1}$ ) & 0.69 & 1.38 & 1.52 & 7.07 \\
\hline Final cell volume $\left(\mu \mathrm{m}^{3}\right)$ & 35 & 36 & 35 & 13 \\
\hline Budded cells $(\%) \ddagger$ & $4 \cdot 8$ & $6 \cdot 1$ & $5 \cdot 4$ & $24 \cdot 6$ \\
\hline
\end{tabular}

but show differences in the stationary phase (Sudbery et al., 1980). The requirement for a high degree of oxygen saturation to express the phenotype suggests that the phenotype is dependent on aerobic growth on ethanol. This conclusion is supported by the observation that a difference in cell size between the mutant and parent strain becomes apparent at the onset of ethanol consumption. This hypothesis was examined by growing cells on ethanol $\left(10 \mathrm{~g}^{-1}\right)$ as the major carbon and energy source. This concentration was chosen since it represents the maximum concentration obtained during growth on glucose. The $\mathrm{dO}_{2}$ concentration was maintained above $70 \%$ saturation. The results (Table 2) show that final cell size, cell density and budding were characteristic of the whi2 phenotype and similar to the final phenotype of cells grown in glucose batch cultures. Interestingly, the specific growth rate of the whi2 strain on ethanol was $78 \%$ higher than that of the wild-type, confirming previous observations (Walton, 1984). Thus while whi 2 cells are identical to the wild-type during fermentative growth on glucose, they show marked differences during aerobic growth on ethanol.

\section{Batch shift cultures grown on $Y P G$}

In order to further examine the role of oxygen in the expression of the whi 2 phenotype, a series of experiments was done in which $\mathrm{WHI}^{+}$and whi2 strains were grown in the 2-litre bioreactor at $\mathrm{dO}_{2}$ concentrations approaching $0 \%$ saturation. During the growth phase, samples $(10 \mathrm{ml})$ were removed at intervals and placed in sterile flasks $(100 \mathrm{ml})$ at $30^{\circ} \mathrm{C}$ on a rotary shaker ( 250 r.p.m.), a speed which ensured $>70 \%$ saturation of the medium with oxygen.

The results (Table 3) show that the whi2 phenotype was not expressed during growth at low oxygen saturation. However, upon transfer to conditions of high oxygen saturation the final cell density, volume and percentage of budded cells were representative of the whi 2 phenotype. The results shown in Table 3 were independent of the time of sampling during the initial anaerobic growth period. Growth, during the initial anaerobic period, ceased after approximately $8 \mathrm{~h}$ due to glucose exhaustion. However, the whi 2 phenotype was expressed when samples taken during 
this $8 \mathrm{~h}$ period, and up to $40 \mathrm{~h}$ after growth had ceased, were transferred to highly aerobic conditions. During the initial $8 \mathrm{~h}$ period, the residual glucose concentration in the medium decreased to zero as it was consumed by the cells for growth and ethanol formation. Consequently the samples transferred during this initial $8 \mathrm{~h}$ period contained a range of glucose and ethanol concentrations which appeared to have no effect on the degree of whi2 phenotype expression.

The results obtained here with batch cultures agree with observations obtained with chemostat cultures. At high dilution rates the feed rate of glucose addition surpasses the ability of cells to metabolize it aerobically even in the presence of an adequate oxygen supply (Fiechter et al., 1981 ; Sonnenleitner \& Käppeli, 1986). The result is an increase in fermentative activity of the yeast. As the dilution rate is decreased the availability of free glucose is decreased and the cells become derepressed. Cell size also changes with dilution rate (Lorincz \& Carter, 1979; Johnston et al., 1979; Lord \& Wheals, 1980) decreasing with decreasing rate until it becomes independent of dilution rate at slow growth rates. The breakpoint of this curve is coincident with the dilution rate at the transition from fermentative to aerobic growth. However, it is not clear whether this is fortuitous (Waiton, 1984). When whi2 cells are cultured in a glucose-limited chemostat the breakpoint of the size/dilution rate curve is shifted towards a slower dilution rate. whi 2 cells are thus smaller than wild-type cells during aerobic growth but identical to wild-type cells during fermentative growth. Thus in both chemostat and batch culture studies the same conclusion is reached that expression of the whi 2 mutation requires aerobic growth. It thus seems likely that expression of the whi2 phenotype requires a pattern of metabolism found during growth on non-fermentable carbon sources such as glycerol, ethanol and acetate (Walton, 1984). The exact significance of this observation is unclear; however, it suggests that examination of the mechanisms involved in catabolite repression, together with the enzymes involved in the control of metabolism, in whi2 cells would further the understanding of this mutation.

Finally, it should be pointed out that the level of aerobicity of the cultures was controlled through automatic control of the rate of agitation of the bioreactor contents. This method was used since the mass transfer rate of oxygen from the gas to the liquid phase of the culture, and thus the $\mathrm{dO}_{2}$ concentration, could be more accurately and rapidly controlled compared with other methods such as varying the air flow rate. It is theoretically possible that the results obtained for expression of the whi2 phenotype were the result of a differential sensitivity of the parent and mutant strains to shear stress imposed by vigorous agitation. However, in view of the above discussion and the relatively low agitation rates employed (150-700 r.p.m.), this would appear unlikely.

This work was supported by an award from the Society of General Microbiology.

\section{REFERENCES}

Deutch, C. E. \& Parry, J. M. (1973). Sphaeroplast formation in yeast during the transition from exponential phase to stationary phase. Journal of General Microbiology 80, 259-268.

FIECHTER, A. (1975). Continuous cultivation of yeasts. Methods in Cell Biology 11, 97-130.

Fiechter, A., Fuhrmann, G. F. \& Käppeli, O. (1981). Regulation of glucose metabolism in growing yeast cells. Advances in Microbial Physiology 22, 123-183.

HARTWELL, L. H. (1974). Saccharomyces cerevisiae cell cycle. Bacteriological Reviews 38, 164-198.

Johnston, G. C., EhrhaRdT, C. W., Lorincz, A. \& CARTER, B. L. A. (1979). Regulation of cell size in the yeast Saccharomyces cerevisiae. Journal of Bacteriology 137, 1-5.

LAGUNAS, R. L. (1986). Misconceptions about the energy metabolism of Saccharomyces cerevisiae. Yeast 2, 221-228.
Lillie, S. H. \& Pringle, J. R. (1980). Reserve carbohydrate metabolism in Saccharomyces cerevisiae: responses to nutrient limitation. Journal of Bacteriology 143, 1384-1394.

Lord, P. G. \& Wheals, A. E. (1980). Asymmetrical division of Saccharomyces cerevisiae. Journal of Bacteriology 142, 808-818.

LORINCZ, A. \& CARTER, B. L. A. (1979). Control of cell size at bud initiation in Saccharomyces cerevisiae. Journal of General Microbiology 113, 287-296.

ParRY, J. M., Davies, P. J. \& Evans, W. E. (1976). The effect of 'cell age' upon the lethal effects of physical and chemical mutagens in yeast. Molecular and General Genetics 146, 27-35.

SAUL, D. J. \& SUdBery, P. E. (1985). Molecular cloning of $W H I 2$, a gene involved in the regulation of cell proliferation in Saccharomyces cerevisiae. Journal of General Microbiology 131, 1797-1806. 

Saul, D. J., Walton, E. F., Sudbery, P. E. \& CARTER,
B. L. A. (1985). Sacharomyces cerevisiae whi2 mutants in stationary phase retain the properties of exponentially growing cells. Journal of General Microbiology 131, 2245-2251.

SChenberg-Frascino, A. \& Moustacchi, E. (1972). Lethal and mutagenic effects of elevated temperature on haploid yeast. 1. Variations in sensitivity during the cell cycle. Molecular and General Genetics 115, 243-257.

SNow, R. (1966). An enrichment method for auxotrophic yeast mutants using 'Nystatin'. Nature, London 211, 206-207.
SONNENLEITNER, B. \& KÄPPELI, O. (1986). Growth of Saccharomyces cerevisiae is controlled by its limited respiratory capacity: formulation and verification of a hypothesis. Biotechnology and Bioengineering 28, 927-937.

Sudbery, P. E., Goodey, A. R. \& Carter, B. L. A. (1980). Genes which control cell proliferation in the yeast Saccharomyces cerevisiae. Nature, London 288 , 401-404.

WaLTON, E. F. (1984). The isolation and study of cell division cycle mutants in Saccharomyces cerevisiae. $\mathrm{PhD}$ thesis, Trinity College, Dublin, Eire. 